\title{
Péče jako individuální odpovědnost a prohloubení ekonomického znevýhodnění sólo matek v pandemii covid-191
}

\section{Radka Dudová}

\section{Care as an Individual Responsibility and the Worsening of the Economic Disadvantages of Solo Mothers during the Covid-19 Pandemic}

\begin{abstract}
The Covid-19 pandemic had a particularly severe impact on people in a vulnerable position, such as solo mothers living alone with their children. In this article I use an intersectional approach in order to understand how their different positions in life affected their ability to cope with the crisis situation. I present a longitudinal qualitative study of the situation of solo mothers in the Czech Republic during the Covid-19 crisis, based on repeated interviews with women from three Czech regions. The preliminary findings indicate that a crucial factor in the women's ability to cope with increased care responsibilities was the kind of job they had before the pandemic hit. Women with higher qualifications and stable jobs faced a decline in income coupled with stress resulting from a conflation of paid work and care. In response, they reduced their professional ambitions. Women who were unemployed or lost their job during the pandemic faced long-term unemployment, and the jobs that they were offered on the labour market were forms of precarious employment. For all of them, irrespective of their work situation, the pandemic deepened their sense of vulnerability, and all of them experienced some form of economic hardship. The lack of any systemic support and the ignoring of the needs of (solo) parents (and children) were accompanied by the individual responsibilisation of the mothers. As a consequence, old inequalities deepened and new ones emerged.
\end{abstract} Keywords: solo mothers, Covid-19, inequalities, labour market discrimination, reproductive work

Dudová, Radka. 2021. Péče jako individuální odpovědnost a prohloubení ekonomického znevýhodnění sólo matek v pandemii covid-19. Gender a výzkum / Gender and Research 22 (2): 110-138, http://dx.doi.org/10.13060/gav.2021.022.

\footnotetext{
1 Tento text vznikl s podporou projektu "Genderové aspekty pandemie: redefinice péče v důsledku krize
} spojené s nemocí covid-19?", financovaného GA ČR, č. 21-13587S. 
Sólo matky byly skupinou často probíranou ve veřejných diskusích o negativních dopadech pandemie covid-19 v průběhu let 2020 a 2021. Domácnosti vedené sólo rodičem patřily již pred pandemií v České republice k těm nejchudším (Čsú 2020), zároveň jsou dlouhodobě ignorovány sociálními politikami (s výjimkou protahované debaty o náhradním výživném). Většinou v jejich čele stojí žena - podle dat Sč́tání 2011 v 85 \% př́padů. Ačkoliv sólo matky nejsou rozhodně homogenní skupinou, některé nevýhody a rizika mají společné bez ohledu na své další charakteristiky. Spojuje je to, že zpravidla samy pečují o své děti a zároveň jsou primárně zodpovědné za jejich ekonomické zajištění. Je pro ně proto velmi důležité, zda a jak mohou kombinovat péči o děti s pracovní aktivitou, prípadně jakým způsobem funguje záchranná sociální sít v okamžiku, kdy pracovat nemohou. Pandemie covid-19 a zejména dlouhodobé uzavření škol včetně škol mateřských a tlak na minimalizaci sociálních kontaktů i s nejbližšími príbuznými znamenaly pro ženy, které žiji samy se svými dětmi, kritické navýšení objemu péče o děti a omezení možnosti pracovat. Charakter ekonomických dopadů pandemie navíc znamenal, že byly ve zvýšené míre omezeny obory a ohroženy typy práce, $v$ nichž pracují ženy a právě sólo matky. Tyto matky navíc měly před pandemií jen velmi malé finanční rezervy a také užší sit sociálních vztahů, jež by jim mohly poskytnout podporu. Proto Ize očekávat, že na ně pandemie dopadla obzvlášt́ negativně.

$\checkmark$ tomto textu prezentuji výsledky kvalitativního výzkumu postavení sólo matek s malými dětmi v průběhu pandemie. Mým cílem je popsat způsoby, jimiž pandemie a okolnosti s ní spojené přispěly k dalšímu znevýhodnění a marginalizaci sólo matek na pracovním trhu, a ukázat, jak různé pozice či zdroje ovlivnily ekonomický dopad krizové situace na ženy. Zkušenosti komunikačních partnerek Ize uchopit jako tři procesy, které vedou ke zhoršení jejich postavení na pracovním trhu a zároveň ke zvýšení jejich ekonomické zranitelnosti. Jedná se o: 1) snižování jejich pracovních aspirací; 2) prekarizaci práce; 3) uvíznutí v dlouhodobé nezaměstnanosti. Vycházím přitom z teorie rizikové společnosti Ulricha Becka (2018) a konceptu kontradikce reproduktivní práce v kapitalismu Nancy Fraser (2016). Využívám intersekcionální přístup k uchopení a analýze dat. Ve výsledku ukazuji, jak na sebe sólo matky přebírají (či je na ně kladena) zodpovědnost za zvládnutí rizika spojeného s pandemií, což přispívá k další vulnerabilizaci této skupiny. Lze proto předpokládat, že negativní dopady pandemie, doprovázené individualizací a responzibilizací jednotlivců a jednotlivkyň, v tomto př́padě sólo matek, budou dlouhodobého charakteru - v podobě mzdové mezery, dalšího zhoršení pracovního postavení těchto matek a negativních dopadů na jejich fyzické a psychické zdraví. 


\section{Zranitelná výchozí pozice sólo matek a nedokonalá kompenzační opatření v době pandemie}

Zpráva z výzkumu VÚPSV zaměřeného na rodiče samoživitele uvádí, že podle dat posledního Sč́tání lidu, domů a bytů z roku 2011 byla čtvrtina rodin se závislými dětmi jednorodičovských; podle dat EU-SILC to bylo $15 \%$. ${ }^{2} Z$ hlediska životní úrovně patří rodiny s jedním rodičem dlouhodobě k těm nejohroženějším. Podle Sčítání lidu, domů a bytů 2011 stála v 85 \% v čele těchto rodin žena. Podle výzkumu VúPSV (Paloncyová et al. 2019). „Samoživitelé 2019", zaměřeného přímo na sólo rodiče, byly děti v šetřených rodinách nejčastěji v převážné péči matky, každé desáté bydlelo více u otce, další desetina střídala bydliště rodiču půl napůl. Se svým druhým rodičem se nestýkalo každé čtvrté dítě, výživné nedostávala přibližně pětina.

Vlastní analýza autorky datového souboru EU-SILC 2018 (Dudová 2020a), srovnávající ekonomické a pracovní postavení sólo matek a matek žijících s partnerem, ukázala, že podle tohoto šetření měly tyto matky v prưměru nižší vzdělání než matky závislých dětí žijící s partnerem; týkalo se to zejména matek svobodných. Byly v podobné míře jako matky s partnerem aktivní na pracovním trhu, ale byly častěji nezaměstnané. Polovina zaměstnaných sólo matek měla hrubé měsíční př́ijmy z hlavního zaměstnání nižší než 21580 Kč. Hlavními znevýhodňujícími faktory, vztahujícími se k postavení sólo matek na pracovním trhu, byly podle dat EU-SILC 2018 nízké vzdělání těchto matek, nižší věk dětí a jejich větší počet. I při kontrole vzdělání, věku a věku nejmladšího dítěte ale zvyšovalo sólo mateřství samo o sobě riziko nezaměstnanosti. Statisticky významně vyšší nezaměstnanost mezi sólo matkami byla tedy zpưsobena nejen jejich nižším vzděláním, ale i samotným faktem, že se starají samy o děti. Tyto matky byly statisticky významně častěji zaměstnané v tzv. prekérních formách práce obvykle pracovaly na smlouvu na dobu určitou a na DPČ nebo DPP $(16,1$ \% z těch, které byly zaměstnané) (Dudová 2020a).

Podle panelového výzkumu agentury PAQ „Život během pandemie“ byli právě lidé pracující v těchto nejistých režimech krizovou situací nejsilněji negativně ekonomicky postiženi. V lednu 2021 se nějaké omezení (ztráta či omezení práce) týkalo 21 \% osob pracujících na dohodu, $15 \%$ OSVČ a $14 \%$ zaměstnanců (Život během pandemie 2020). Sólo matky v souboru EU-SILC 2018 častěji než muži, ale i běžněji než matky žijící s partnerem pracovaly v odvětvích, která byla v rámci protipandemických opatření úplně uzavřena nebo omezena (v obchodu a službách, v oblasti osobních služeb

\footnotetext{
2 Podle (Paloncyová et al. 2019) je důvodem podhodnocení podílu jednorodičovských rodin v databázi EU-SILC kromě zatížení dat výběrovou a nevýběrovou chybou i relativně malá ochota domácností se šetření účastnit, což se v případě opakovaných návštěv v rámci tzv. panelu projevuje ve stále selektivnějším okruhu typů domácností.
} 
a osobní péče). Navíc méně často pracovaly na kvalifikovaných pozicích, kde je vyšší šance využít práci z domova.

Výzkum STEM z přelomu ledna a února 2021, zaměřený prímo na rodiny samoživitelů a samoživitelek v koronavirové krizi, ukázal, že u 43 \% neúplných rodin se během uplynulého roku zhoršila finanční situace a $35 \%$ má nižší př́ijem než před rokem. Častěji jde přitom o ty rodiny, které již před krizí byly v horší výchozí situaci, mají nižší př́ijmy nebo problémy se splácením pưjček, postrádají podpưrný okruh příbuzných a známých a mají vztahové problémy s rodičem svých dětí (s dopadem na platby výživného). ${ }^{3}$

Vedle ohrožení pracovních míst sólo matky výrazně negativně ovlivnilo uzavření škol a školek. Školy včetně mateřských byly v ČR v průběhu pandemie uzavřeny v období od března do května 2020, potom v říjnu až listopadu 2020 a poté od ledna do května 2021. Školy byly uzavřeny celkem na 20 týdnů pro děti v mateřských školách, 25 týdnů pro děti v první a druhé trrídě, 35 týdnư pro děti ve třetí až páté třídě a 44 týdnů pro děti na druhém stupni základní školy. Školy v tomto období poskytovaly distanční výuku. Forma i úroveň distanční výuky se v různých školách lišila, zejména pro rodiče mladších dětí představovala významnou zátěž. Podle výzkumu „Život během pandemie" trávilo na jaře 202025 \% rodičů s dětmi každý den učením čtyři a více hodin; více času trávili rodiče učením s dětmi na prvním stupni ZŠ. Na podzim 2020 naopak narostl čas, který škole věnovali rodiče dětí na druhém stupni, především u rodičů s nižším vzděláním, z nichž se téměř polovina věnovala učení s dětmi čtyři a více hodin denně (Korbel, Prokop 2020).

$\checkmark$ době, kdy kvưli péči o děti rodiče nemohli pracovat, jim měla př́ijem nahradit dávka „ošetřování člena rodiny" (OČR). Ta je v běžných dobách vyhrazena zaměstnaným rodičům dětí do deseti let věku s účastí na sociálním pojištění a je omezena na devět kalendářních dní pro rodiče žijící v partnerství a 16 dní pro sólo rodiče. Jakmile bylo žrejmé, že školy nebudou fungovat déle než dva týdny, začala diskuse o úpravě této dávky, aby lépe odpovídala situaci pandemie. Dne 24. března 2020 byla výplata dávky prodloužena na neurčito po celou dobu trvání školní uzávěry a nárok byl rozšířen pro děti do 13 let věku. Dne 30. dubna byl se zpětnou platností zvýšen náhradový poměr z 60 \% na 80 \% redukovaného výpočtového základu, což v praxi znamenalo, že pro rodiče s nižšími príijmy se dávka OČR př́liš nelišila od výše čisté mzdy nebo platu. Toto rozhodnutí ale bylo přijato s poměrně velkým zpožděním a rodiče se tak nemohli rozhodovat s plnou znalostí podmínek. Nárok na dávku OČR byl poměrně rychle přiznán i pro osoby samostatně výdělečně činné. Avšak ženy a muži pobírající rodičovský př́spěvek nebo kombinující podnikání se zaměstnáním byli z tohoto nároku vyloučeni. Teprve 30. dubna byl po dlouhých diskusích nárok na OČR rozšířen

${ }^{3}$ Viz https://www.stem.cz/vyzkum-k-situaci-samozivitelu-a-samozivitelek-v-koronavirove-krizi/\#more-6349 


\section{NV STATI / ARTICLES}

na osoby pracující na krátkodobé a jednorázové dohody, pokud se v rámci těchto dohod účastnily nemocenského pojištění a zároveň musely pečovat o děti po dobu trvání dohody. Takto nastavené podmínky ovšem vylučovaly většinu brigádně pracujících rodičů.

Na podzim bylo "krizové ošetřovné" schváleno až 30. řijna 2020, tedy dva týdny poté, co byly školy znovu plošně uzavřeny. Tentokrát se dávka ale vztahovala již jen na děti do deseti let věku a výměra byla stanovena na $70 \%$ denního vyměřovacího základu (DVZ). Nárok na ošetřovné trval opět po celou dobu uzavření škol. V době třetí vlny (březen-květen 2021) byla výměra dávky znovu navýšena na 80 \% DVZ; zvýšení dávky ale bylo schváleno až zpětně na konci března 2021 s platností od začátku měsíce.

Vedle dávky OČR vztahující se $k$ péči o děti měli někteří rodiče nárok na kompenzace př́ijmu, pokud kvůli pandemii a protipandemickým opatřením byla omezena jejich práce. Zaměstnankyně a zaměstnanci pracující v omezených sektorech mohli být doma a pobírat náhradu mzdy. Vládní program Antivirus kompenzoval zaměstnavatelům a zaměstnavatelkám náklady na toto opatření. Dne 9 . dubna 2020 byl schválen paušálně stanovený „kompenzační bonus" pro osoby samostatně výdělečně činné ve výši 500 Kč na den. Teprve 10. července 2020 byl nárok na kompenzační bonus rozšířen i na osoby pracující na dohodu (o provedení práce a o pracovní činnosti), pokud byly čtyři měsíce v půlroce před březnem 2020 účastny nemocenského pojištění a kvưli pandemii nemohly vykonávat svou pracovní činnost. Tuto podmínku opět mohla splnit jen malá část z nich. Část pracujících sólo rodičũ tak do těchto vládních kompenzačních programů nespadala.

$\checkmark$ situaci, kdy se řada lidí včetně rodičů náhle dostala kvůli protipandemickým opatřením do nepř́znivé finanční situace, představovala jediný nástroj pomoci sociálního státu jednorázová nenároková dávka mimořádná okamžitá pomoc (MOP). V dubnu 2020 MPSV upustilo od testování majetku (kromě finančního zůstatku na účtu) při žádosti o tuto dávku. Přesto se při vyhodnocení v březnu a dubnu 2020 ukázala mimořádná okamžitá pomoc jako neefektivní nástroj, nedostupný pro cílovou skupinu, a to zejména kvůli fyzickému uzavření poboček úřadů práce. V říjnu 2020 byly dále upraveny podmínky čerpání mimořádné okamžité pomoci a v př́padě nouze způsobené pandemií ji bylo možné čerpat nově i na splátku hypotéky. Přes avizovanou snadnost a dostupnost dávky se ale stále jednalo o dávku nenárokovou, tj. přidělení záviselo na posouzení konkrétním úřadem práce.

Sólo matky nepředstavují homogenní skupinu, i když je spojuje vyšší odpovědnost za péči a zároveň za ekonomické zajištění vlastní rodiny. Liší se mezi sebou svým vzděláním a pracovním postavením, ale také věkem, etnicitou, sexuální orientací a strukturou rodiny. Každá pravděpodobně zakoušela dopady pandemie trochu odlišně v závislosti na průsečíku jednotlivých charakteristik. Všechny se ale 
nacházely ve zranitelné pozici v okamžiku, kdy přestaly fungovat veřejné i soukromé služby péče o děti včetně škol, jelikož právě na nich záviselo jejich nastavení rovnováhy mezi placenou prací a péčí, bez možnosti podělit se o část odpovědnosti s druhým rodičem.

\section{Kolize reproduktivní a produktivní práce v době „neoliberální pandemie"}

Pro uchopení sociálních souvislostí pandemie nemoci Covid-19 je prínosné konceptualizovat pandemii jako realizaci globálního rizika, jak jej rozpracovává ve své teorii rizikové společnosti Ulrich Beck (Beck 1992). Za prvé, riziko je podle Becka sociálně konstruovaný fenomén. Jeho podstatou je to, že o něm nemáme dostatek jasných informací. Někteří lidé přitom mají větší možnosti definovat povahu rizika než ostatní. Moc vymezit rizika se proto stává hlavní linií nerovnosti v moderní společnosti. Mocní aktéři a mocné aktérky mají možnost maximalizovat rizika pro ostatní a minimalizovat rizika sami pro sebe (Beck 2006: 333). Za druhé, rizika jsou individualizována. To znamená, že každý jednotlivec a jednotlivkyně musí ve výsledku zvládat nejistotu v moderním světě sám/sama, což je důsledkem toho, že expertní systémy nutně selhávají v racionálním managementu rizik. Aniž by měl k dispozici racionální vědění či pomoc institucí, jedinec je volán k zodpovědnosti - má se chovat tak, aby sám/sama naprosto neznámým a nepředvídatelným rizikům předcházel/ předcházela. „Volání po zodpovědnosti” je podle Becka cynismus, kterým instituce zakrývají svá vlastní selhání (tamtéž: 336). Jedinec si má tedy poradit sám, zároveň ale nemůže uniknout moci definice rizika ze strany expertních systémů. Např́klad pokud expertní a politické instituce vykládají riziko celosvětové pandemie primárně jako riziko zdravotní, a nikoli jako například riziko nedostatku péče, riziko ekonomické nebo vzdělanostní, musí se jedinec podvolit vládním opatřením, jež z této definice vyplývají (omezení sociálních kontaktů; zavření obchodů, služeb a škol), a zároveň sám nebo sama nese negativní následky, které toto vymezení přináší. Beck také ríká, že tváŕí v tvár̆ riziku padá platnost společenské smlouvy či nároku na veřejné statky (tamtéž: 342). Očekává se, že jednotlivci se sami postarají o své sociální zajištění a vytvoří si zásoby pro prípad katastrofy. A za třetí, podle Becka realizace rizika, tedy katastrofa, dopadá nejprve na chudé. Globální rizika prohlubují sociální zranitelnost a celosvětově nejhưře dopadají na lidi znevýhodněné, bez zdrojů a př́stupu k moci. Způsob, jakým jsou rizika definována, je zpravidla slepý k tomu, že ne všichni mají zdroje a možnosti se pred nimi chránit nebo minimalizovat jejich dopad.

Pokud se zaměříme na situaci sólo matek (nejen v ČR, ale i jinde ve světě), je zřejmé, že představují skupinu, která vzhledem ke své nízké politické reprezentaci a aktivitě neměla možnost mluvit do toho, jak bylo riziko spojené s pandemií nemoci covid-19 


\section{STATI / ARTICLES}

definováno. Zároveň se stávají těmi, na něž toto riziko dopadá velmi významně. Sociální nerovnosti, které byly vítěznou definicí rizika generovány, souvisely: a) s typem placené práce, tedy zejména s tím, zda bylo možné ji nadále vykonávat a mít př́jem, zda bylo možné ji vykonávat z domova a tím sní̌it riziko nákazy své a svých blízkých a zároveň mít více možností pečovat; b) s tím, zda měl jedinec či rodina dostatečné finanční rezervy, aby měl/měla čím pokrýt výpadek př́ijmů, případně zda má nárok na sociální př́ijmy, které nebyly krizí (zatím) ohroženy; c) s tím, zda byly v rodině přítomny děti a jakého byly věku, d) zda mohl daný jedinec čerpat pomoc od své sociální sítě / svých blízkých, či naopak oni potřebují jeho/její pomoc. Od žen, jež žily samy s dětmi, se implicitně očekávalo, že budou schopny pokračovat ve výdělečné práci, i když přestaly fungovat veřejné instituce zajištujuící péči o děti a vzdělávání, prípadně že budou mít finanční rezervu k tomu, aby vykryly výpadek př́ijmů a mohly zůstat $s$ dětmi doma a vyučovat je.

$\checkmark$ době vytvoření rizika přestala platit společenská smlouva, která byla do té doby nezpochybnitelná. Nejen sólo rodiče, ale všichni rodiče malých dětí spoléhali na to, že o jejich děti je po určitou část dne postaráno veřejným vzdělávacím systémem, a tento čas tedy mohou věnovat výdělečné činnosti. Tento systém ale přestal na jaře 2020 ze dne na den fungovat a rok poté je nadále jeho fungování nejisté. Veškerá zodpovědnost za péči se tak rázem přenesla na rodiče. Toto přenesení zodpovědnosti na jedince si v rodinách se dvěma rodiči zpravidla vyžádalo navýšení počtu hodin strávených péčí o děti u obou rodiču a transformaci genderových rolí, at' už k vyššímu zapojení otců, kteří zůstali doma na homeoffice nebo omezili práci, nebo ke zvýšení pečovatelské zátěže matek a jejich stažení se z trhu práce (viz např. Czymara, Langenkamp, Cano 2020; Del Boca et al. 2020; Feng, Savani 2020; Shafer, Scheibling, Milkie 2020; Chung et al. 2021; Fuller, Qian 2021; Hipp, Bünning 2021).

Výzkum (Hertz, Mattes, Shook 2020) zaměřený na sólo matky v době pandemie poukázal na to, že ačkoliv situace představovala stres pro všechny rodiče, pro tyto matky byla extrémně obtí̌ná. Situace sólo matek je specifická v tom, že zátěž produktivní a reproduktivní / pečovatelské práce spočívá v zásadní miře na jedné osobě, a poručení společenské smlouvy péče (viz Esping-Andersen 2002) pro jejich domácnosti může mít skutečně destruktivní důsledky. Výzkum Rosanny Hertz a jejích kolegyň (Hertz, Mattes, Shook 2020) se zaměřil na ženy ze střední nebo vyšší střední třídy, které se staly sólo matkami na základě dvou předpokladů: že budou po porodu nadále zaměstnané a že se někdo (jedinec nebo organizace) bude starat o jejich děti, zatímco budou pracovat. Zatímco fungování jejich domácnosti záviselo na oddělení času (a zpravidla i prostoru) věnovanému práci a péči, pandemie přinesla zhroucení hranic mezi těmito dvěma sférami. Př́liš vysoká intenzita pečovatelských nároků ve spojení s nutností pokračovat v práci z domova ústily v přetí̌ení, stres a snížení kvality jejich vztahu s dětmi. Příznačné je, že tyto ženy popisovaly svou neschopnost zvlád- 
nout obojí jako své osobní selhání, nikoliv jako strukturní problém (Hertz, Mattes, Shook 2020: 22).

Situace pandemie tak zvýraznila paradox vztahu reproduktivní a produktivní práce v kapitalismu, který konceptualizovala r̆ada feministických autorek. Podle Nancy Fraser je pro kapitalismus obecně charakteristická "kontradikce sociální reprodukce" (Fraser 2016). Na jedné straně je sociální reprodukce nezbytnou podmínkou pro dlouhodobě udržitelnou akumulaci kapitálu, na straně druhé tendence kapitalismu k neomezené akumulaci vede $k$ destabilizaci samotného procesu sociální reprodukce, na níž přitom závisí. Jinak řečeno, bez rození dětí a péče o ně, vzdělávání dětí, starání se o staré a nemohoucí, péče o komunitu okolí, prírodu a o sdílené významy a kulturu, která umožňuje kooperaci, není kapitalismus možný. Zároveň se ale kapitalismus ve svých různých formách snaží sociální reprodukci potlačit, destabilizovat a znemožnit. Způsob organizace sociální reprodukce $v$ neoliberalismu neboli finančním kapitalismu podle Fraser spočívá v omezení veřejných služeb, co největším stlačení času disponibilním pro pečující práci, v marketizaci péče, přesunutí sociální reprodukce na chudší ženy a budování stále delších "řetězů péče". V době pandemie a souvisejících lockdownů tento přesun péče náhle nebyl tak snadný. „Pandemie zviditelnila drsnou realitu této krize reprodukce, která znevýhodňuje na základě intersekcionálních rozdílü" (Ozkazanc-Pan, Pullen 2021).

Ulrich Beck a Elisabeth Beck-Gernsheim podobně poukázali na vnitřní rozpor pozdního kapitalismu, který Beck nazývá "reflexivní modernou”. To je ve zkratce druhá fáze vývoje moderny, jež se obrací proti sobě samé, jelikož plodí rizika, která ji vzápětí ohrožují. Příkladem takového rizika je individualizace, jež sice umožňuje jednotlivcům vyvázat se z předem definovaných pravidel a povinností, ale zároveň na něj či na ni klade veškerou odpovědnost za jeho/její situaci. Individuum si může budovat svou vlastní biografii, ale jen okolo trhu práce a v závislosti na něm. Požadavky trhu práce však zásadním způsobem kolidují se zájmy rodiny, tedy se zájmy sociální reprodukce. Ideálním zaměstnancem nebo ideální zaměstnankyní je totiž absolutně mobilní a flexibilní jedinec, soutěživý a ambiciózní, ignorující veškeré své závazky v soukromé sféře (Beck, Beck-Gernsheim 1995: 23). Jedinci (muži i ženy) tak $\checkmark$ procesu individualizace museli převzít odpovědnost za svou vlastní biografii, tedy i za svůj úspěch či neúspěch na pracovním trhu, přičemž právě pozice na pracovním trhu definuje v pozdním kapitalismu jejich celkové společenské postavení. Pokud jsou rodiči, v pandemii na nich ležela i plná odpovědnost za zajištění péče o děti, jelikož přestala platit společenská smlouva určující rozdělení péče mezi rodinu, stát a trh. Pandemie tak naplno vyjevila zranitelnost sólo matek v neoliberálním či pozdním kapitalismu, jelikož byly náhle plně individuálně zodpovědné jak za produktivní, tak reproduktivní práci.

Jak konstatuje Beck, riziko dopadá nejhůře na lidi znevýhodněné. Ti totiž nema- 


\section{NV STATI / ARTICLES}

jí žádnou nebo mají jen velmi omezenou možnost zasahovat do definice rizika, ale nesou většinu nákladů s touto definicí spojených. To značí, že vhodným přístupem pro uchopení dopadů pandemie na životy jedinců je přístup intersekcionální (Collins, Bilge 2016; viz Kř́žková, Formánková 2014). Celková pozice jedince a jeho schopnost zvládat krizovou situaci není totiž pouhým součtem jeho charakteristik, ale vyplývá z průsečíku os pozic a z(ne)výhodnění, na nichž se jedinec nachází. Intersekcionální přístup chápu jako teoretický a metodologický přístup ke zkoumání sociálních nerovností (Kolářová 2008). Jeho cílem je zkoumat provázanost různých zdrojů nerovností a procesů z(ne)výhodňování. Na rozdíl od přístupu, ve kterém jsou zdroje nerovností (např. vzdělání, etnicita nebo gender) analyticky považovány za vzájemně nezávislé, intersekcionální výzkum aplikuje "multiplikativní" přístup (Choo, Ferree 2010: 131). Ten se př́mo zaměřuje na zkoumání toho, jak se zdroje nerovností ve svém vlivu vzájemně utvářejí. Patricia H. Collins (1990: 276) hovoří o existenci struktury nerovností, jež se vztahuje k různým oblastem distribuce moci (strukturální, disciplinující, hegemonické a interpersonální). Podle tohoto prístupu jsou systémy nerovností neoddělitelně propojeny a (re)produkují se na různých úrovních od struktury společnosti přes instituce, symboly a normy až po individuální praktiky. $\vee$ rámci této struktury mưže jedinec zažívat zároveň znevýhodnění i zvýhodnění podle svého konkrétního kombinovaného statusu (Browne, Misra 2005: 489).

Metodologicky využívám vnitroskupinový (intra-categorical) intersekcionální př́istup (McCall 2005). V tomto zpravidla kvalitativním př́stupu jsou struktury nerovností využívány jako kontext pro zkoumání zkušeností a prožívání z(ne)výhodnění a procesů z(ne)výhodňování u konkrétní skupiny, v tomto případě konkrétní skupiny sólo matek během pandemie. Při vnitroskupinovém přístupu se postupuje od intersekcionálního celku (tj. sociální skupiny, události nebo konceptu) k výzkumu vzájemných souvislostí a provázanosti jednotlivých forem z(ne)výhodnění či procesů z(ne) výhodňování.

Dostupná data naznačují, že zásadní osou z(ne)výhodnění v době pandemie bylo rodičovství a zodpovědnost za děti. Další osou je tradičně třída či socioekonomické postavení. Významná byla i konkrétní pracovní pozice a typ pracovního vztahu. Dále mưžeme uvažovat o ose věku, etnicity či (dis)ability. Nejedná se tedy jen o rozdíl v pozicích těch, kdo mají a kdo nemají závazky péče, ale i o rozdíly uvnitř skupiny rodičů. Někteří otcové a matky mají větší zdroje, možnosti a manévrovací prostor než jiní, a tudíž se dokážou lépe vyrovnat s negativními dưsledky, které splynutí sféry produkce a reprodukce, práce a péče přináší. Situace rodičů se bude lišit v závislosti na jejich socioekonomickém postavení, vzdělání, typu a odvětví placené práce či rozsahu pomocné sociální sítě, jež dokážou mobilizovat, na počtu a věku dětí nebo na jejich zdravotním stavu a ohrožení onemocněním covid-19. Zároveň je možné využít koncept kompenzujících zvýhodnění, rozvíjený zejména v pedagogice a v sociologii 
nerovností a sociální stratifikace (viz např. Bernardi, Gil-Hernández 2021). Podle něho ti, kteří byli před vypuknutím pandemie nějak zvýhodněni, mohli využít toto zvýhodnění pro lepší zvládnutí krize neboli kompenzování jejích negativních dopadů. Rodiny a jednotlivci, kteří před pandemií měli více ekonomických a sociálních zdrojů, je mohli mobilizovat, aby jejich propad nebyl tak citelný. Naopak ti, kdo byli před pandemií znevýhodněni, neměli krizové dopady čím kompenzovat a jejich znevýhodnění se tak výrazně prohloubilo.

Kvalitativní analýza zkušeností sólo matek v průběhu pandemie má za cíl ukázat, jak odlišné výchozí pozice ovlivnily to, jak tyto matky zvládaly krizovou situaci spojenou se zneplatněním společenské smlouvy péče a které odlišné mechanismy zhoršují jejich pozici na pracovním trhu, což posléze ovlivňuje jejich celkové socioekonomické postavení i postavení jejich dětí. Zároveň umožňuje nastínit odpověd' na otázku, jak pozice žen v průsečících různých charakteristik a os z(ne)výhodnění ovlivňují jejich situaci a zvládání krize a zda (a jak) tyto pozice přispívají ke „kompenzaci” znevýhodnění.

\section{Metodologie}

V tomto článku vycházím z longitudinálního kvalitativního výzkumu sólo matek, provedeném ve třech regionech ČR (střední Čechy, Olomoucko a Ústecko). Výzkum byl ve své první fázi realizován pro organizaci Aperio - Společnost pro zdravé rodičovství, z.s., v rámci projektu OPZ „Sama, ale silná: Odstraňujeme diskriminaci sólo matek na trhu práce" formou skupinových rozhovorů (fokusních skupin) s matkami žijícími se svými dětmi bez jejich otce. Jeho záměrem bylo uskutečnit na jaře 2020 šest skupinových rozhovorů - dva v každém regionu. Skupinové rozhovory s ženami ze Středočeského a Olomouckého kraje proběhly v průběhu února a na začátku března 2020, tedy těsně před spuštěním protipandemických opatření reagujících na začátek šíření nemoci covid-19. Skupinové rozhovory v Ústeckém kraji se konaly v červnu 2020 po ukončení nouzového režimu a věšiny protipandemických opatření. Skupinových rozhovorů se účastnilo celkem 48 žen - 15 v Praze, 20 v Olomouci a 13 $\checkmark$ Ústí nad Labem. Skupinové rozhovory vycházely ze shodných scénářů, byly vedeny zkušenou moderátorkou a trvaly 3-4 hodiny. Ženy, které debatovaly ve fokusních skupinách, žily samy $v$ domácnosti se svými dětmi a měly zájem o účast v projektu, který jim měl pomoci zlepšit jejich pracovní postavení. Jednalo se o ženy se všemi úrovněmi nejvyššího dosaženého vzdělání, v různorodých pracovních pozicích, rodinných situacích a ekonomickém postavení. Okruhy témat probírané ve skupinách se týkaly jejich současné pracovní pozice a spokojenosti v ní, bariér a možností včetně rovnováhy mezi pracovním a osobním životem, zkušeností s předsudky a diskriminací na pracovním trhu, příjmů a ekonomické situace, sebevědomí, strategií přežití či úspěchu. 


\section{NV STATI / ARTICLES}

$\checkmark$ reakci na pandemii covid-19 jsem ve Středočeském a v Olomouckém kraji na přelomu května a června 2020 provedla dodatečné telefonické individuální rozhovory s těmi komunikačními partnerkami, které v době skupinových rozhovorů pracovaly a měly děti mladší 13 let (druhá vina rozhovorů). Rozhovory byly zaměřeny prrímo na dopady a reflexi situace kolem pandemie covid-19. Doplňujících rozhovorů se zúčastnilo celkem 14 žen, sedm ze Středočeského a sedm z Olomouckého kraje. Telefonické rozhovory trvaly mezi 15 a 40 minutami a byly nahrány a přepsány pro potřeby analýzy. Dotazované ženy tvořily v polovině př́padů vysokoškolačky a v polovině prípadư středoškolačky. Dvanáct jich bylo zaměstnaných, z toho tři na dobu určitou a dvě byly ve zkušební lhưtě, dvě ženy pracovaly na dohodu o provedení práce. Skupinové rozhovory v Ústeckém kraji zahrnuly otázky pokládané v těchto dodatečných rozhovorech a reflektovaly tak dopady první viny pandemie prímo, jelikož byly prováděny až v červnu 2020. Těchto skupinových rozhovorư se účastnilo 12 žen, pět z nich mělo základní vzdělání, dvě byly vyučené, jedna středoškolačka a čtyři vysokoškolačky. $\vee$ tomto kole sběru byly ženy dotazovány na to, jak je a jejich rodinu zasáhla pandemie covid-19, konkrétně jak se dotkla jejich práce a ekonomické situace, jak řešily péči o děti a domácí vzdělávání, jak situaci zvládaly psychicky, co pro ně bylo v situaci lockdownu nejobtížnější, kde získávaly pomoc a podporu a zda na této situaci vnímaly něco pozitivního.

Třetí vlna rozhovorư proběhla v zimě 2021, po skončení podzimní vlny pandemie. Telefonické rozhovory byly zopakovány s 12 ženami ze Středočeského a Olomouckého kraje (jednu respondentku se nepodařilo kontaktovat a jedna se znovu vdala a nastoupila na mateřskou dovolenou). Dále byly provedeny tři doplňující telefonické rozhovory se ženami z Ústeckého kraje (více o komunikačních partnerkách viz tabulku $v$ príloze). Třetí vlna sběru dat se zaměřila na dlouhodobé zvládání krize. Byly přitom kladeny stejné otázky jako ve druhém kole rozhovorů.

Účastnicím rozhovorů byla zaručena anonymita, v dalším textu jsou označeny přezdívkami a veškeré citlivé údaje byly anonymizovány. Rozhovory byly zvukově zaznamenány a následně přepsány pro potřebu analýzy.

Pro analýzu dat jsem zvolila prístup reflexivní tematické analýzy, rozpracovaný psycholožkami Virginií Braun a Victorií Clarke (Braun, Clarke 2006). Tematická analýza je metoda zahrnující identifikování, analýzu a interpretaci vzorců významů neboli "témat" v rámci kvalitativních dat. Zahrnuje flexibilní proces kódování, přičemž teprve postupem procesu kódování jsou konstruována témata. Braun a Clarke chápou témata jako vzorce sdílených významů uvnitř dat, sjednocené ústředním konceptem, které jsou klícové pro porozumění danému fenoménu a významné pro zodpovězení výzkumné otázky. Témata jsou výsledkem systematického kódovacího procesu. Výzkumník či výzkumnice hraje aktivní úlohu při vytváření témat - konstruuje je či generuje, k čemuž využívá své vlastní porozumění a paradigmatické a teoretické zakotvení. 
Postup analýzy zahrnuje podrobné a opakované čtení materiálu, poté proces kódování s využitím softwaru pro analýzu kvalitativních dat Atlas.ti. Po kódování textu jsem identifikovala významné kategorie a vytvořila a popsala témata. Analýza se zaměřila primárně na to, jak sólo matky v různých pracovních a osobních situacích zvládaly události spojené s první a druhou vinou pandemie covid-19, jaké dopady měla protipandemická opatření na jejich pracovní životy a ekonomickou situaci a jaké předpokládaly dlouhodobé dopady "koronakrize". Výsledná témata (snižování aspirací, uvíznutí v nezaměstnanosti a zacyklení v prekérní práci) představují procesy či mechanismy vyplývající z vyprávění komunikačních partnerek, které jednotlivě i souběžně vedly ke zhoršení ekonomického postavení dotazovaných žen v době pandemie covid-19.

\section{„Mohla bych brát jedenapůlkrát tolik": Snižování pracovních a jiných aspirací}

První kolo skupinových rozhovorů se sólo matkami, které proběhlo ještě před začátkem pandemie covid-19, ukázalo, že ústřední kategorií charakterizující jejich pracovní situaci byl pracovní sestup (viz Dudová 2020b). Komunikační partnerky již pred pandemií velmi často pracovaly na pozicích, jež neodpovídaly jejich vzdělání, předchozím zkušenostem ani schopnostem. Ženy se jednoduše snažily získat a udržet jakoukoli práci, která by jim umožnila pečovat o děti a zároveň rodinu alespoň nějak ekonomicky zajistit, i když nutně neodpovídala jejich vzdělání a původním ambicím. Doplňující rozhovory ukázaly, že období pandemie covid-19 tuto tendenci ještě prohloubilo.

O snížení svých profesních ambicí hovořily dotazované ženy ze všech vzdělanostních skupin, ale v tomto oddílu se zaměříme zejména na ty, které měly vyšší vzdělání a před pandemií poměrně stabilní práci s průměrnými či vyššími př́ijmy. Tato situace se týkala především Pavly, Klaudie a Eriky. Pavla pracovala v Praze jako IT specialistka na zkrácený úvazek a na jaře 2020 měla děti ve věku deset a sedm let. V době prvního rozhovoru na konci února 2020, tedy ještě před pandemií, vyjadřovala nespokojenost s úrovní své mzdy. Byla si vědoma, že v jiné firmě by za stejnou práci mohla dostat více peněz, a zůstávala hlavně díky vstřícným pracovním podmínkám. Chystala se požádat svého zaměstnavatele o zvýšení, a pokud by jí nevyhověl, chtěla si hledat lépe placenou pozici.

Takže tam pro mě samozřejmě nastane ten jako nepríjemný bod, kdy já budu muset zvažovat, jestli [pokračovat]dál, nebo jestli budu muset hledat jinou práci, která bude jako finančně lepší, ale zase samozřejmě tam bude velký risk a asi nikdy nebudu mít tak super podmínky, jako mám ted'. (Pavla, 41 let, VŠ, projektová manažerka v IT, dvě děti, jedenáct a osm let, SČ, únor 2020) 


\section{NV STATI / ARTICLES}

V červnu, kdy jsem s ní hovořila podruhé, se ale již obávala, že její zaměstnavatel negativně pocítí důsledky ekonomické krize a nebude ke slíbenému zvýšení mzdy ochoten. Kvưli omezení provozu byly naopak plošně sníženy odměny v celé organizaci. Zaměstnavatel byl ale velmi vstřícný ohledně rozvržení pracovní doby, navíc na jaře 2020 lehce poklesly pracovní nároky. Z loajality proto ani Pavla neuvažovala o odchodu z práce či o čerpání ošetřovného, na něž by měla nárok. Naopak hodnotila pozitivně to, že se jí kvưli péči o děti nesnížil příjem:

Vlastně i potom, co se všechno začalo uvolňovat a já jsem třeba čekala, jestli príjde to, že musíme zase všichni nastoupit do kanceláře nebo tak, tak naopak teda z HR poslali dotazník o tom, co by lidi preferovali. To byla každopádně velká pomoc, protože ve chvili, kdy by to bylo třeba nějak striktni, tak bych řekněme musela jit na tu ošetřovačku, ale tam zase samozřejmě finančně [by to] pro nás byla rána, protože už takhle je to takové od výplaty do výplaty. A pak samozřejmě každý výpadek nebo snižení je citelný.

(Pavla, červen 2020)

V posledním rozhovoru v prosinci 2020 vyprávěla, že pohovory s osobním oddělením, plánované na záři 2020, byly odsunuty na neurčito, a tudiž se ani nezvýšila mzda, přestože to bylo pưvodně avizováno. Zároveň se ale ke konci roku výrazně navýšil objem práce, kterou musela vykonávat, takže poměrem k odpracovaným hodinám se její odměna významně snízila. Pavla si ale v tento okamžik uvědomovala podle svých slov ještě silněji, že díky vstřícnosti svého zaměstnavatele může v práci pokračovat i přesto, že pečuje o dvě děti ve věku 11 a 8 let, jež nemohou chodit do školy. Byla vděčná za částečný úvazek a za možnost pracovat plně z domova:

Tak pro mě není varianta tu práci neudělat. Jednak si vážím hodně toho, že mi ten zaměstnavatel vychází vstříc se zkráceným úvazkem a i vlastně s podmínkami, které já potřebuji. A tudiž nepovažuji jednak za fér a jednak ani za... za taktické, křičet "ne, já to nemůžu udělat, já to neudělám”. Takže samozřejmě se snažím všechnu tu práci udělat. Ale je to za cenu toho, že tedy tomu věnuju víc hodin. Takže zatímco $v$ absolutnich částkách ten pokles přijmů není až tak znatelný, tak ve chvili, kdy se na výplatní pásce třeba objevuje prüměrný hodinový výdělek, tak jsem zjistila, že v podstatě se mi snižila, a ted' neřikám jenom za tu covid krizi, ale za poslední dva roky, když jsem si to sledovala, v podstatě třeba o sto korun na hodinu. (Pavla, prosinec 2020)

O hledání jiné práce již v zimě neuvažovala. Doufala, že ke zvýšení její mzdy nakonec někdy dojde, jelikož firma byla postižená ekonomickým utlumením jen zčásti. Práci 
se věnovala dopoledne, když děti měly on-line výuku, a večer. Odpoledne s dětmi doháněla školu a pomáhala s úkoly.

Prostě děti se musely naučit respektovat, že když prijjdou za mnou, nebo když zavolají, že neprijjdu. A když za mnou prĭjdou a já jim ukážu, že to nejde, tak že to prostě nejde a že na mě mluvit nemohou. Nicméně samozřejmě děti alespoň moje - nefunguji tak, že když jim ukážu, že se jim nemůžu věnovat, že by si tedy ty věci do školy nebo ty věci, co by měly udělat, dělaly samy. (Pavla, prosinec 2020)

Péče o děti spočívala převážně jen na ní. Během jara ani podzimu 2020 nechtěla žádat o pomoc své rodiče, protože by je nerada ohrozila možnou nákazou, otec dětí si děti vzal k sobě jen na několik víkendů. Díky flexibilitě své práce zvládala péči i placenou práci i v době uzavření škol. Vnímala to jako benefit, který jí vynahrazoval nižší mzdu. Klíčové pro ni bylo, aby měla dostatek času pro své děti, a nepřemýšlela tak již o možnosti změnit práci a hledat nějakou lépe ohodnocenou.

U mě ty vztahy ve firmě a ty podminky, které mi ten zaměstnavatel poskytuje, jsou ještě na dalších pár let pro mě natolik zásadní, že skutečně změnu zaměstnání budu řešit až v momentě, kdy skutečně už nevyjdu teda finančně (...). Vím, že bych mohla brát řekněme jedenapůlkrát tolik, třeba, ale ted'se bavíme o ekvivalentu plného úvazku, a... a já prostě nejsem v situaci vzhledem $k$ tomu, jak na tom jsou děti. (Pavla, prosinec 2020)

Omezení práce a prríjmu se týkalo i Klaudie, která byla zaměstnaná jako marketingová manažerka. Náplň její práce, tedy pořádání rưzných akcí pro firmy a veřejnost, byla protipandemickými opatřeními silně dotčena. Zatímco v rozhovoru v červnu 2020 hovořila o zvýšené pracovní zátěži v době první vlny pandemie, jelikož bylo nutné najít nové zpưsoby práce a naučit se je, dále řešit přechod firmy na digitální fungování, v zimě 2020/2021 již pocítila pokles objemu práce. To také znamenalo snížení jejího př́ijmu o třetinu, jelikož ten byl z velké části tvořen odměnami, na něž neměla nárok:

No, na jednu stranu mi teda ubylo tolik zápřahu (...). Na druhou stranu ubyly mi prémie, prostě jsem tam za základni mzdu plus nějaké pevné odměny. A každopádně takové ty odměny za extra práci, tak samozřejmě nepřichází, protože neni extra práce. Na tom je bitý vlastně můj rodinný rozpočet, protože s tím jsem počitala. Takže ano, je méně práce a méně peněz. (Klaudie, 34 let, SŠ, pracovnice v marketingu, dvě děti, jedenáct a devět let, OI, prosinec 2020) 


\section{NV STATI / ARTICLES}

Na jaře se cítila velmi přetížená péčí o své dvě děti ve věku 11 a 9 let a zvažovala, že měla raději zvolit odchod na ošetřovné než práci z domova. Nejprve se ale chtěla vyhnout snižení svého príijmu, které by ošetřovné ve výši 60 \% redukovaného denního výpočtového základu nutně představovalo. Navíc cítila, že její práce ve firmě je nezbytná a zaměstnavatel jí vyšel vstříc s rozvržením času práce. Zvýšení ošetřovného kvưli pandemii na 80 \% bylo schváleno až 30. 4. 2020, kdy již podle ní bylo pozdě rozhodnout se být s dětmi plně doma. Rozhodování o výši dávek „ex post" se zpětnou platností tak zvyšovalo nejistotu rodičů a neumožňovalo jim informovaně se rozhodovat. I další ženy s vyššími pracovními příjmy, které se nejprve rozhodly pracovat z domova, protože si nemohly dovolit snižení přijmů, posléze podle svých slov svého rozhodnutí litovaly. Kdyby věděly, jak dlouho bude trvat uzavření škol a jak bude náročné kombinovat péči a práci z domova a že ošetřovné bude nakonec zpětně navýšeno, raději by se plně soustředily na péči o děti.

Mám dvě děti na prvním stupni a obě dvě jsem musela nejdřív [obstarat], prostě všechno, tisknout materiály, dělat jim plány učiva, učit je, kontrolovat to, pomáhat jim s tím a bylo to, do toho teda pracovat, protože ty výkony po mně ta práce chtěla, a to jsem vlastně dodělávala po nocích, třeba do jedné, do dvou do rána. Takže jsem v osm ráno měla budiček i s dětma a nastoupila jsem další směnu. Takže to bylo hodně vyčerpávající. (...) Že po pravdě jsem se pak sama zamrzela nad tím, že jsem si nevzala to OČR, že bych měla o to méně starostí. (Klaudie, červen 2020)

V zimě již péči a vzdělávání dětí zvládala, ale za cenu významného snížení př́imu a nejistoty práce. S poklesem objemu práce se Klaudie začala obávat toho, že o práci priijde úplně:

Eventy, jak všichni víme, se nedělají, tak je zase pro mě takové očekávání, jestli si mě ponechají, jestli budu mít nějakou práci, a pokud, tak jestli to nebude nějaká méně hodnotná práce, kterou bych nechtěla dělat. A musela bych jí dělat, protože mi nic jiného nezbyde. (Klaudie, prosinec 2020)

Erika, vystudovaná právnička, pracovala jako asistentka soudce a měla osmileté dítě. Podobně jako ostatní snižila své pracovní ambice ještě před pandemií. Ačkoliv pưvodně se chtěla stát soudkyní a na pozici asistentky nastoupila pouze dočasně, po narození dítěte a následném rozvodu cítila, že ke kariérnímu postupu nemá dostatečnou podporu od svých nadřizených: 
Tak už jsem začala pocitovat to, že jsem rozvedená a každý mi řiká "no, to se do ničeho nehrň, protože jak to budeš zvládat, jseš sama s ditětem", takže tam člověk pocitoval takový ten odstup. (Erika, 37 let, VŠ, soudní asistentka, jedno dítě, osm let, Ol, únor 2020)

Zaměstnavatel jí nebyl ochoten nijak vyjít vstříc ohledně sladění práce a péče, dítě bylo vnímáno jako „individuální problém”, jenž si musí vyřešit sama. Práce asistentky ve státní sfére jí ale poskytovala stabilitu, kterou v době pandemie velmi ocenila, a o změně práce neuvažovala.

Přesto pro ni a její rodinu pandemie znamenala zásadní zhoršení situace. Její nový př́tel, se kterým začala na jaře 2020 žít, jako živnostník přišel o zakázky a neměl z čeho splácet své závazky. Eričin př́ijem byl pro jejich společnou domácnost jediný a navíc čelili exekuci dluhu. $V$ zimě, poté co byl její partner dlouhodobě bez práce a vyčerpala všechny finanční rezervy, popisovala svou situaci takto:

Ale já jsem třeba přestala spát, přestala jsem jíst, já jsem z toho byla tak vystresovaná, takže musela jsem sáhnout, byt' tady ty věci nikdy neschvaluju, ale prostě poprvé jsem musela si dát nějaký prášek na spaní (...). (Erika, listopad 2020)

Obtížné bylo pro ni i zvládání práce z domova a on-line výuky syna. Přechod na on-line vyučování namísto týdenního zadávání úkolů na podzim pro ni zkomplikovalo situaci, jelikož musela svou placenou práci podřizovat synovu vyučování:

To se setkává v jeden čas, že jo, i já reaguju na rưzné pracovní věci... když jsou různé telefonáty, prostě většinou se ty věci řeši dopoledne. A on-line výuka je taky dopoledne, že. Do toho máme jeden počitač, takže jak to jako jde skloubit. (Erika, listopad 2020)

Dalo by se říci, že tyto ženy, které měly stabilní zaměstnání, jež si zachovaly v průběhu pandemie, a navíc mohly pracovat z domova, se nacházely oproti ostatním ve zvýhodněné pozici. Díky práci na homeoffice mohly zajistit péči o děti a jejich podporu během distančního vzdělávání. Jejich příběhy ukazují, že i ženy disponující zdroji, jež by je mohly v krizové situaci ochránit před zásadním zhoršením jejich socioekonomické situace, čelily riziku a ztrátám. To na jedné straně proto, že náročnost péče o děti se v době uzavření veřejných institucí péče a vzdělávání několikanásobně zvýšila. Na druhé straně proto, že ve své práci pocítily dopady ekonomického utlumení, a to i na pozicích, kde bychom to príliš nečekali. Oba faktory se totiž prolínaly: závazek péče o děti znamenal, že se necítily prríliš jisté v tom bojovat za svou pozici, naopak ještě 


\section{NV STATI / ARTICLES}

slevily ze svých nároků a jen doufaly, že neztratí své pracovní místo. Pokud před pandemií usilovaly o pracovní postup nebo vyšší plat, na tyto ambice rezignovaly. Naopak se smiríily se sní̌ením príijmů nebo úvazku, protože vnímaly, že produktivita jejich práce je omezená kvưli péči o děti. Musely zároveň zastat několik pracovních směn - odvést svou práci pro zaměstnavatele nebo zaměstnavatelku, jejiž objem se navíc dočasně zvýšil, a postarat se o děti, pomáhat jim se školou, vařit pro ně a uklízet. Svou nižší pracovní výkonnost, sníženou tím, že děti nemohly navštěvovat školu, vnímaly jako svưj individuální problém. Neočekávaly pomoc ani od státu, ani od svého okolí, byly vděčné, když jim zaměstnavatel nebo zaměstnavatelka vyšel/vyšla vstříc natolik, aby mohly setrvat na své pozici, a to i za cenu toho, že se snízil jejich hodinový přijem. $\checkmark$ důsledku celkového zhoršení ekonomické situace opustily aspirace na získání kvalifikovanější nebo lépe placené práce. Jejich přiběhy naznačují, jak může ekonomické ochlazení v kombinaci se znevýhodněnou pozicí (sólo)rodiče vést k prohloubení genderové mzdové mezery: ženy se smiřují se snížením mzdy nebo rezignují na její zvýšení, protože si chtěji zachovat alespoň to, co mají, a obávají se, že kvůli péči o děti budou právě ony v organizaci více ohroženy ztrátou zaměstnání. Vzdělání, pracovní zkušenosti a zaměstnání v kvalifikovaném oboru jim tak sice v době pandemie poskytly alespoň nějakou jistotu, neochránily je ale od ekonomických a profesních ztrát.

Nutnost zajistit péči a vzdělávání dětí v době školních uzávěr a zároveň zvládat placenou práci pro tyto ženy představovala ohromnou zátěž; i přesto ji vnímaly jako svou primární a individuální zodpovědnost. Sólo mateřství zvyšovalo jejich zranitelnost, jelikož péče o děti spočívala v naprosté většině jen na nich. Stát se v době pandemie vyvázal ze svého dílu zodpovědnosti za péči a vzdělávání dětí. Komunikační partnerky reagovaly na toto porušení sociální smlouvy tím, že přijaly tuto zodpovědnost za svou a byly vděčné svým zaměstnavatelům a zaměstnavatelkám za časovou flexibilitu. Zároveň byly matky pretížené kumulací rolí a souběhem placené a neplacené práce, což se negativně podepisovalo na jejich pohodě a duševním zdraví.

\section{„Jsou doma, a já nemůžu vůbec nic dělat": Uvíznutí v dlouhodobé nezaměstnanosti}

V odlišné situaci se nacházela skupina sólo matek, které před pandemií neměly práci nebo o ni přišly v jejím průběhu. Na jaře 2020 neměly tři z 15 dotazovaných žen práci, v zimě jich bylo bez práce pět. Další pracovaly nižší počet hodin týdně než před pandemií. Všechny tyto ženy hovořily o tom, jak je v době opakovaných lockdownů a školních uzávěr obtí̌né, až nemožné najít si novou práci.

No, ted' je to docela těžký, protože já jsem měla nastoupit do práce a děti jsou ted'doma, takže nemůžu. A ta třetí dcera právě taky měla nastoupit do školky, 
která je taky zavřená. Takže hodně tady trnu, že jsou doma a já nemůžu vůbec nic dělat. (Zoe, 27 let, ZŠ, rodičovský príspěvek, tři děti, osm, sedm a tři roky, Ús, březen 2021)

Na vině byla opět celková ekonomická situace a negativní dopad protipandemických opatření na řadu odvětví, a tudíz nízká poptávka po pracovní síle, a dále to, že musely doma pečovat o děti a učit se $s$ nimi. Školy a školky byly střídavě zavírány $v$ rámci celostátních lockdownů nebo kvůli karanténám, matky se musely opakovaně narychlo přizpưsobovat novým podmínkám. Proto nebyly vnímány zaměstnavateli či zaměstnavatelkami jako perspektivní pracovní síla a mnohdy samy vyhodnotily, že nemá smysl pokoušet se nastoupit do nové práce.

Adéla v únoru 2020, kdy přišla o práci, zvažovala, že půjde pracovat do Německa, jelikož bydlí blízko hranic, má dlouholetou praxi v administrativě a hovoří výborně německy. Potom ale byly uzavřeny hranice a zavřely se školy. Byly sice otevřeny před prázdninami, tehdy ale pro ni nemělo smysl si práci hledat, jelikož by musela během prázdnin ve zkušební době zajistit péči o jedenáctiletého syna. Nechala tedy hledání práce na zárí. $V$ září obešla několik konkurzů, během měsíce ale byly školy opět zavřeny a ona se rozhodla, že raději bude synovi dál doma pomáhat se vzděláváním. Naštěstí měla ještě z doby před narozením dítěte dostatečnou finanční rezervu, kterou ovšem pưvodně chtěla použít pro pořízení nemovitosti. Neuměla si ale představit, že by syn zvládl být dlouhodobě sám doma a že by se to dalo skloubit s prací:

I kdyby on tu školu dělal poctivě, tak by tady byl sám do odpoledne, do čtyr hodin, a kdybych chodila do práce, prǐšla bych z práce a on by mi řekl "no hele, viš mami, my máme tohle, tohle, tohle a já s tím potřebuju pomoct", a já tohle nevím, to učivo vưbec neznám. (...) Kdybych chodila do té práce a pak prǐšla, byla vyřízená, tak si myslím, že to bych asi nedala. (Adéla, 41 let, SŠ, nezaměstnaná, jedno dítě, jedenáct let, Ús, leden 2021)

$\checkmark$ některých prípadech tedy matky cítily, že děti potřebují jejich pomoc s distančním vzděláváním, i když děti byly starší deseti let a teoreticky se očekávalo, že zvládnou být dlouhodobě doma samy. Tomuto očekávání odpovídalo nastavení dávky ošetřovného, na které na podzim 2020 již neměli nárok rodiče dětí starších deseti let. Pokud se matky nenacházely $v$ takové pracovní pozici, aby mohly pracovat $z$ domova, a nechtěly nechat děti dlouhodobě doma samotné, raději rezignovaly na placenou práci.

Dvě ženy, Anna a Aneta, přišly o práci v létě 2020 , ačkoliv ještě na jaře byly zaměstnané. $\vee$ obou případech to bylo spojené s vyšší zátěží v práci, kterou nebylo možné vykonávat z domova, v kombinaci s péčí o děti, jimž nefungovaly školy a školky. Adéla pracovala jako zdravotní sestra u praktického lékaře, přičemž obtižnost práce vzrost- 


\section{NV STATI / ARTICLES}

la kvưli pandemii. Své tři děti nechávala samotné doma. Stres u ní spustil zdravotní problémy, kvưli kterým se nakonec v záŕí rozhodla dát výpověd'.
A já jsem tam i byla ve velkém stresu z té práce a začala jsem mit zdravotní problémy a věděla jsem, že prostě tam nemůžu jako fungovat, že nezvládnu takhle náročnou práci a péči o tři děti, no. A bylo to pro mě hrozně těžký rozhodování, protože jsem si řikala, že tohle si jako nemůžu dovolit. (Aneta 37 let, SŠ, zdravotní sestra, tři děti, jedenáct, osm a pět let, Ol, prosinec 2020)

Anna zase pracovala na poště, kde byla rozšířena pracovní doba a vzrostly přesčasy, což nemohla zvládat spolu s péčí o malého syna. Byla přesvědčená, že v práci vydrží i během prázdnin, kdy měla slíbenou pomoc od matky, a od září si bude hledat práci novou. Nakonec ale koncem června zdravotně zkolabovala. Aneta si v prosinci znovu našla práci zdravotní sestry na kratší úvazek, kam měla nastoupit od ledna 2021. $\checkmark$ době rozhovoru v prosinci ale ještě netušila, že děti v lednu již do školy nenastoupí, a navíc že od března bude zavřená i školka pro nejmladšího.

No jako trochu se obávám toho, když nastoupím někde do práce a bude zase dalši vina a zase zavřou školy, tak bud' teda nechám děcka samotný, budou to muset teda nějak zvládat, a budu chodit do práce, anebo tam bude riziko toho, že budu ve zkušební době a půjdu na OČR a vyhodí mě. Tak z toho mám trochu strach, no. Jako doufám, že už se třeba nestane, že po Vánocích prostě třeba bude měsíc zavřená škola. To už mě teda trochu děsí. (Aneta, prosinec 2020)

Respondentky pocitovaly zhoršení situace na pracovním trhu na vlastní kůži také v tom, že zaměstnavatelé a zaměstnavatelky, se kterými se setkávaly př̀i hledání práce, na podzim začali být podle jejich vyprávění ještě více „vybíraví než předtím, byli méně ochotni vycházet pracujícím matkám vstříc a sólo matky předem diskvalifikovali.

No a mně prijjde, že ted' ty mámy samoživitelky, jak ted' je ta krize, tak je to horší. Jakmile něco malinko trošku nesplňujete nebo potřebujete ráno jet o půl hodiny dýl, s tím, že tam odpoledne zưstanete o půl hodiny dýl, tak to ted' moc ty zaměstnavatelé nějak nechtěji vycházet vstříc. (Anna, 43 let, SŠ, poštovní doručovatelka, jedno dítě, čtyři roky, SČ, prosinec 2020)

Již dřive znevýhodněné postavení sólo matek na pracovním trhu se v důsledku ekonomického ochlazení pravděpodobně ještě zhoršilo, navíc matky byly mnohem více vnímány jako "rizikové pracovnice", protože závazek péče o dítě v době pandemie 
znamenal nejen potřebu přizpůsobit pracovní dobu, ale také hrozbu, že pracovnice bude muset ze dne na den zůstat doma s dětmi, protože se zavřely školy či školky. To, že se stát vyvázal z odpovědnosti za zajištění vzdělávání a péče o děti po část dne, vedlo $k$ tomu, že komunikačním partnerkám nezbýval žádný čas pro produktivní práci, pokud se jednalo o práci vykonávanou mimo domov. Jakmile spočívala veškerá reproduktivní práce jen na nich (často se jednalo o ženy s větším počtem dětí a bez pomoci širší rodiny či blízkých), nemohly se věnovat práci placené. Bylo tomu tak paradoxně i v prípadě takové práce, která byla veřejně označena jako v pandemii "klíčová", tedy práce zdravotní sestry.

Dlouhodobá nezaměstnanost znamenala, že ženy se svými rodinami přežívaly na hranici chudoby nebo pod ní. Ženám, které již před pandemií pobíraly sociální dávky, se sice př́ijmy nezměnily, ale zvýšily se jim náklady. Problém představovalo uzavření školních jídelen, protože nutnost vařit dětem zvýšila jejich náklady na jídlo. Některým respondentkám pomáhaly neziskové organizace, dobrovolné asociace či charity. Ty, jež přišly o práci nebo jim skončila podpora v nezaměstnanosti před nedávnou dobou, hovořily o tom, že se jim vůbec nedaří dávky získat, například proto, že by se musely vzdát svého majetku nebo proto, že mají trvalé bydliště jinde, než skutečně bydlí. Pro sólo matky, které před pandemií svou situaci jakž takž zvládaly, ale neměly takové př́ijmy, aby si mohly vytvářet finanční rezervy, byla situace nejpalčivější. Sociální sít jim žádnou okamžitou pomoc neposkytla a kvůli výpadku př́ijmů se dostávaly ve svých rozpočtech do minusu. Neměly ve zvyku žádat o pomoc stát nebo charitu a cítily se náhle stigmatizované jako "sociální prípady".

Zkušenosti komunikačních partnerek při hledání nové práce potvrzovaly odpojení a vytěsnění reprodukce ze sféry produktivní práce (viz Fraser 2016; Beck, Beck-Gernsheim 1995): zaměstnavatelé a zaměstnavatelky požadovali takové pracující, kteří nebudou limitováni péčí o děti a nebudou představovat riziko, že v prípadě další vlny pandemie budou muset upřednostnit zodpovědnost za péči. Komunikační partnerky neviděly možnost, jak se zříci zodpovědnosti za péči o vlastní děti; zároveň tato péče (včetně odpovědnosti za vzdělávání, která již několik století náleží do veřejné sféry) nebyla v jejich prípadě nijak ohodnocena. Její hodnota totiž byla nadále plně odvozena od pozice matky ve světě placené práce.

\section{„Krachuje to na tom, že mi nabídnou tu dohodu“: zacyklení v prekérní práci}

Práce, jež se respondentkám v této situaci při hledání nabízela, byla často jen práce na dohodu, bez pevné pracovní smlouvy nebo mimo formální systém. Stela, která před rodičovskou dovolenou pracovala jako kvalifikovaná speciální pedagožka, se po rozvodu při rodičovské s nejmladším dítětem rozhodla brigádně pracovat jako 


\section{NV STATI / ARTICLES}

skladnice-balička. V únoru 2020 plánovala, že od září její nejmladší dítě nastoupí do školky a ona bude hledat práci odpovídající jejímu vyššímu vzdělání. Namísto toho ale musela snízit své zapojení na brigádě ze tří na jeden den v týdnu, kdy jí byla kamarádka ochotná pohlídat děti. Na hledání lepší práce prozatím rezignovala. Naopak byla vděčná, že může takto flexibilně pracovat dál:

Ta práce byla a tím, že jsem brigádnik, jsem čekala, že právě třeba mi řeknou, že mě nepotřebujou, ale naopak práce bylo daleko víc. (Stela, 42 let, Vక̌, balení zboží, tři děti, dvanáct, devět a pět let, SČ, červen 2020)

Prekérní pracovní úvazky prijímaly i ženy, které měly ve svém hlavním zaměstnání výpadek prríjmů a potřebovaly si někde přivydělat. Laura, zaměstnaná v divadle, si našla dočasnou brigádu v supermarketu na nočních směnách, kde mohla pracovat, když její malý syn spal; jelikož bydlela společně se svou matkou, nemusela v noci řešit hlídání.

Takže můžu jenom se uskromnit, plus si hledat ještě něco navic, co jde.

Což v téhle době je opravdu jako kasa, doplňování, vožení jídla a podobně. (Laura, 29 let, VOŠ, kostymérka, jedno dítě, tři roky, SČ, červen 2020)

Obecně respondentky sehnaly spiše práci pod svou úrovní kvalifikace. Byly ochotné dělat víceméně cokoliv, aby měly alespoň nějaký př́jem. Anna, jež přišla v červnu o práci, to vnímala velmi negativně. Celý život byla zaměstnaná ve standardním pracovním poměru (plný úvazek v jednom povolání, smlouva na dobu neurčitou, viz např. Vosko 2006), a nyní jedinou možností, která se jí nabízela, byla nízko kvalifikovaná a nejistá brigáda. Uvědomovala si, že taková práce nezakládá nárok na sociální a důchodové pojištění a může do budoucna vést k dalšímu zhoršení její situace.

\footnotetext{
Ale prostě mně je čtyřicet tři let a já nebudu dělat nikde jako v šestnácti, sedmnácti brigádně. To já zase mám jako vizi jasnou. A je to jenom z toho důvodu, že tam za mě neodváději sociální, zdravotní, nemám nárok na dovolenou, nemám nárok na ošetřováni ditěte a prostě bojím se toho, že když s tím dítětem omarodím, tak oni mi řeknou no, tak už nechod'te, že jo. (...) Vlastně krachuje to na tom, že když chci jit jako prodavačka, tak prostě by mě brali, ale nabídnou mi tu dohodu. (Anna, 43 let, SŠ, poštovní doručovatelka, jedno dítě, čtyři roky, SČ)
}

Do její zkušenosti znevýhodnění ve světě placené práce tak vstupovala i osa věku: zatímco Laura ve 29 letech vnímala prekérní práci jako dočasnou epizodu a cestu, jak se momentálně vyrovnat s krizovou situací, Anna nejistou práci považovala za př́liš 
velké riziko a zároveň za znehodnocení své dlouholeté praxe ve standardních pracovních vztazích. Vyšší vzdělání a pracovní zkušenosti sice ženy do určité míry před prekérními typy práce uchránily, přesto byly tomuto riziku vystaveny i vysokoškolsky vzdělané ženy, které měly malé děti, jako například Stela. Další vysokoškolačky hledaly kvůli skloubení práce a péče práci ve školství jako asistentky pedagoga, kde se jim ovšem nabízely jen časově omezené a nízké pracovní úvazky. Ženy se středoškolským vzděláním s maturitou, jako Anna či Laura, zjištovaly, že jiný typ práce než dohoda se jim na pracovním trhu vůbec nenabízí.

Brigádní a neformální práce sólo matkám neposkytovala žádnou jistotu a zpravidla nezakládala nárok na státní kompenzace spojené s pandemií. Ženy pracující na dohodu neměly nárok čerpat dávku OČR, když musely přerušit práci kvưli uzavření škol, jelikož jejich výdělky nezakládaly účast na nemocenském pojištění. Jediným řešením, jak si zachovat práci a príijem, tak bylo pracovat v noci, pokud tedy mohly nechat děti doma samotné nebo žily se svými rodiči, kteří mohli děti pohlídat. Soňa, jež si k malému pracovnímu úvazku asistentky pedagoga přivydělávala jako samostatně výdělečně činná fotografka, zase neměla nárok na žádné kompenzace pro živnostníky, ačkoliv se její př́ijem o polovinu snížil, protože její podnikání bylo vedlejší činností. Sociální politiky a kompenzační opatření nijak nereflektovaly reproduktivní práci, navíc byly třídně a intersekcionálně slepé, jelikož kompenzovaly příjem jen relativně úzké skupině pracujicích ve standardních pracovních poměrech. Nebraly napríklad v úvahu situaci, kdy pracující ženy skládaly několik rưznorodých malých pracovních úvazků, aby dosáhly př́ijmu, se kterým mohly přežít, tak jako Soňa. Ženy kombinující různé malé zdroje pracovních př́jmů v nejistých pracovních vztazích neměly nárok na nic.

Pandemie tak prohloubila riziko pádu do pasti prekérní práce, kdy sólo matky musely vzít za vděk nejistou, krátkodobou, nízko ohodnocenou brigádní prací, aby si udržely alespoň nějaký př́ijem. Přijetí takové práce ale může znamenat omezení možnosti najít si lepší práci později (Hašková, Dudová 2017). Již v době před pandemií sólo matky ve vyšší míře než ostatní pracující, i než matky stejně starých dětí žjící $\mathrm{s}$ partnerem, pracovaly $\vee$ nestandardních pracovních vztazích. $\vee$ době pandemie se podle zkušeností mých komunikačních partnerek stávala z tohoto typu práce jediná dostupná možnost, nejspíše také v důsledku toho, že zaměstnavatelé a zaměstnavatelky vnímali jako př́liš rizikové zaměstnat sólo matky, jež mohou kdykoliv práci přerušit kvůli uzávěře školy. Z toho Ize usoudit na možné prohloubení prekarizace práce této specifické skupiny v důsledku protipandemických opatření. Pandemie tak přispěla k prohloubení individualizace rizik na pracovním trhu. Príjetím prekérního pracovního vztahu na sebe sólo matky braly odpovědnost za rizika, kterou dřive nesl zaměstnavatel nebo zaměstnavatelka. Přebíraly na sebe rovněž odpovědnost za rizika související s pandemií a vládními pokusy ji regulovat - jak za riziko omezení podnikání, tak za riziko vypovězení sociální smlouvy o péči ze strany státu. Stávaly se „jednorázovou” 


\section{NV STATI / ARTICLES}

a snadno nahraditelnou pracovní silou. Ne náhodou je tento proces $v$ době pandemie takto žretelně pozorovatelný právě u matek malých dětí, ačkoliv se pravděpodobně "systém flexibilního, plurálního a individualizovaného neúplného zaměstnání" (Beck 2018: 151) bude do nějaké míry týkat všech pracujících. Právě u sólo matek se totiž naplno ukazuje kontradikce reproduktivní a produktivní práce (Fraser 2016), tedy to, že „plně realizovaná tržní společnost je také společností bez dětí” (Beck 2018: 190).

\section{Závěr}

V březnu 2020 se stalo realitou něco do té doby nepředstavitelného: kvưli šiření nového virového onemocnění byly velmi rychle za sebou uzavřeny hranice národních států, uzavřeny nebo omezeny celé segmenty ekonomiky, omezena osobní svoboda a byly dlouhodobě uzavřeny školy. Podle Ulricha Becka bychom tyto události mohli označit jako světovou katastrofu neboli uskutečnění globálního rizika. Prvotní sociologické a feministické úvahy směřovaly $k$ tomu, že tato situace naplno vyjeví význam a důležitost péče (Branicki 2020; Thomason, Macias-Alonso 2020). Zvýšená péče o sebe a o druhé se logicky stala strategií zvládání pandemie a náplní práce mnoha lidí. Objevily se úvahy, nakolik setření hranic mezi prací a domovem, produkční a reprodukční prací přispěje $k$ uznání a ocenění péče a $k$ redistribuci pečovatelské práce uvnitř domácností (viz např. Fodor et al. 2020). Po roce a půl trvání pandemie ale pưvodní optimismus spiše vyprchal (Ozkazanc-Pan, Pullen 2021). Výpovědi sólo matek $v$ mém výzkumu ukázaly, že péče o děti byla i v průběhu světové zdravotní krize v ČR nadále konstruována jako individuální odpovědnost. Namísto aby ukázala hodnotu péče pro společnost, pandemie prohloubila nerovnosti mezi těmi, kdo péči poskytují, a těmi, kdo ji poskytovat nemusejí. Jak píše Alessandra Mezzadri, pandemie ukázala naplno nedostatky režimu reprodukce, na němž stojí globální kapitalistický systém, a stala se tak primárně „krizí reprodukce” (Mezzadri 2020). Komunikační partnerky, které byly v době pandemie samy zodpovědné za péči o své děti a zároveň za ekonomické zajištění své rodiny, se dostávaly do neřešitelné situace, na niž systém kapitalistické práce ani systém státního sociálního zabezpečení nedokázaly nijak reagovat. Péče o děti, kterou ve svých domovech vykonávaly, jako by neměla žádnou hodnotu pro nikoho jiného než pro ně samé, a ony ji vykonávaly dál v podstatě navzdory systému. $\vee$ rozhovorech zároveň nevyjadřovaly žádné pochybnosti o tom, že jsou plně odpovědné za zajištění péče o své děti. Bez zaváhání tak v krizi préebíraly plnou individuální odpovědnost za péči, jež byla předtím rozdělena mezi ně jako rodiče a veřejnou sféru.

Rozhovory se sólo matkami ukazují, že katastrofa v podobě pandemie postihla hưře jednotlivce znevýhodněné, bez zdrojů a př́stupu k moci (Beck 2006). Specificky dopadla na všechny osoby primárně zodpovědné za neformální péči; výsledek byl 
ale podmíněn jejich pozicemi v rozsáhlé síti nerovností, zvýhodnění a znevýhodnění. Prožívání a zvládání krize se lišilo v závislosti na postavení a charakteristikách konkrétní ženy. Sólo matky s vyšším vzděláním a relativně stabilní pracovní situací měly lepší výchozí pozici - některé mohly pracovat z domova, prípadně čerpat ošetřovné. Tyto ženy řešily zejména problém spojený s prolnutím času a prostoru pro placenou a reprodukční práci. Při práci z domova se víceméně samy staraly o děti a zajištovaly jejich školní výuku. Ve výsledku byly přepracované, a přesto čelily poklesu svých př́jmů a nejistotě práce, na což reagovaly snížením svých pracovních a kariérních ambicí. Lze očekávat, že tato dynamika nadále povede k prohlubování genderové mzdové mezery.

Pro další ženy pandemie naopak predstavovala ztrátu nebo omezení placené práce. Uzavření celých segmentů ekonomiky a zároveň omezení sociálních kontaktů vedlo k tomu, že pro ty, které práci neměly nebo o ni přišly, bylo velmi obtížné novou práci najít. Místa, jež pro ně byla na pracovním trhu dostupná, se často vyskytovala v sektorech, které se ani přes pandemii nezastavily a představovaly vy̌̌ší riziko nakažení (pokladní, skladnice, pošta a rozvážkové služby). Zpravidla se zároveň jednalo o práce na "dohodu", tj. bez jistoty a sociálního pojištění. Tento typ placené práce se nyní jako jediný nabízel i ženám, jež dřive měly kvalifikovanou práci na standardní smlouvu. Závazek péče o děti se pro ně stal ještě větším hendikepem, jelikož zaměstnavatelé a zaměstnavatelky na sebe odmítli převzít riziko, že kvůli opětovnému uzavření škol nebo školek zaměstnankyně nebude moci pracovat. Matky tak ztratily ochranu sociálního a nemocenského pojištění a riziko spojené s pandemií - uzávěry škol a podniků - nesly plně na svých bedrech. Rozhovory naznačují, že se snízila i ochota zaměstnavatelů a zaměstnavatelek vycházet matkám vstříc ohledně pracovních podmínek.

Některé z komunikačních partnerek se dostaly do situace dlouhodobé nezaměstnanosti. $\vee$ situaci střídavě či kontinuálně nefungujících škol a školek a nemožnosti využít jiné pomoci s péčí o děti kvưli nutnosti omezení osobních kontaktů i v rámci širši rodiny prostě pracovat nemohly, pokud nechtěly nechat děti doma samotné. Tato situace ukázala "díry" v záchranné síti systému sociální podpory: vzhledem k tomu, že př́ijmy pro nárok na sociální dávky se dokládají zpětně, neměly na žádnou pomoc několik měsíců po ztrátě práce nárok. O kompenzace zř́zené kvůli pandemii bud' nemohly žádat vůbec (protože pracovaly v prekérních režimech práce již před pandemií), nebo je dostávaly až s několikaměsíčním zpožděním. Vzhledem $k$ předešlým nízkým výdělkům většinou neměly dostatečné finanční rezervy. Roli státu do velké míry přebíraly soukromé charity a neziskové organizace, které reagovaly okamžitě a pružně.

Pandemie $v$ tomto ohledu prohloubila stávající nerovnosti mezi primárním a sekundárním pracovním trhem: pro ty zaměstnané ve standardních pracovních vztazích český stát spustil řadu kompenzačních programů a investoval nemalé zdroje na záchranu pracovních míst. Projevilo se to $v$ relativně malém nárůstu nezaměstnanosti ještě rok po nástupu pandemie. Oproti tomu osoby pracující v nejistých, dočasných a prekérních 


\section{STATI / ARTICLES}

režimech práce, častěji právě ženy se závazky péče (viz Hašková, Dudová 2017), zpravidla na kompenzace neměly nárok a v sociálním systému se propadaly na dno. Sólo matky, které do té doby nějak dokázaly svou rodinu zajistit, najednou neměly peníze ani na jídlo pro děti, upadaly do chudoby a vyrovnávaly se s poklesem společenského statusu. Jejich pečující práce se stala péči druhé kategorie, jelikož nebyla státem nijak kompenzována. Její ocenění se plně odvíjelo od jejich pozice ve světě placené práce. Zároveň byla péče z hlediska pracovního trhu rizikem, jež musely nést samy.

$U$ všech dotazovaných sólo matek se v průběhu pandemie zhoršila jejich ekonomická pozice, ovšem některé disponovaly zdroji, které jim umožnily ztráty částečně kompenzovat. Pro prvotní zvládnutí krize bylo klíčové, zda měly nějaké finanční rezervy. Z dlouhodobého hlediska bylo významnější to, zda měly práci umožňující pracovat z domova a zda pracovaly v odvětví, jež nebylo omezeno protipandemickými opatřeními. $\vee$ době uzavřených vzdělávacích institucí nabyla na důležitosti dostupnost pomoci s péčí o děti - ženy, které žily v domácnosti se svými rodiči nebo se mohly spolehnout na jejich pomoc či na pomoc otce dětí, měly výrazně více možností, jak péči zkombinovat s placenou prací. Žena v pozici sólo matky pracující ve státním sektoru a žijící v domácnosti se svou matkou na tom tak byla ve výsledku lépe při zvládání uzavření škol než žena v pozici sólo matky, jež pracovala jako manažerka a neměla nikoho, kdo by se alespoň část dne postaral o její děti, ačkoliv před nástupem pandemie měla ta druhá významně vyšší prríjem i finanční rezervy než ta první. Pandemie tak svým zpưsobem „zamíchala kartami” - závazky péče o děti spolu s uzávěrami škol proměnily dřívějši struktury nerovností. Skutečný výsledný účet pandemie bude ale zřejmý až s větším časovým odstupem, až bude zřejmé, jak ekonomika zareaguje na skončení kompenzačních opatření a zda nejistota ohledně fungování institucí péče o děti a vzdělání bude pokračovat. Pandemie v př́bězích žen pečujících samostatně o děti v každém prípadě zřetelně ukázala nespravedlnost systému, ve kterém hodnota péče vychází z pozice jedince na trhu práce, zatímco produktivní práce spočívá na zneviditelnění reproduktivní práce a v jejím odsunutí do sféry individuální odpovědnosti.

\section{Literatura}

Beck, U. 1992. Risk Society: Towards a New Modernity. London: Sage (Theory, Culture \& Society Series), https://doi.org/10.2307/2579937.

Beck, U. 2006. Living in the World Risk Society: A Hobhouse Memorial Public Lecture given on Wednesday 15 February 2006 at the London School of Economics. Economy and Society 35 (3): 329-345, https://doi.org/10.1080/03085140600844902.

Beck, U. 2018. Riziková společnost. Na cestě k jiné moderně. Praha: Sociologické nakladatelství (SLON).

Beck, U., E. Beck-Gernsheim. 1995. The Normal Chaos of Love. Cambridge: Polity Press.

Bernardi, F., C. J. Gil-Hernández. 2021. The Social-Origins Gap in Labour Market Outcomes: 
Compensatory and Boosting Advantages Using a Micro-Class Approach. European Sociological Review 37 (1): 32-48, https://doi.org/10.1093/esr/jcaa034.

Branicki, L. J. 2020. COVID-19. Ethics of Care and Feminist Crisis Management. Gender, Work and Organization 27 (5): 872-883, https://doi.org/10.1111/gwao.12491.

Braun, V., V. Clarke. 2006. Using Thematic Analysis in Psychology. Qualitative Research in Psychology 3 (2): 77-101, https://doi.org/10.1191/1478088706qp063oa.

Browne, I., J. Misra. 2005. Labor-market Inequality: Intersections of Gender, Race, and Class. Pp. 165-189 in M. Romero, E. Margolis (eds.). The Blackwell Companion to Social Inequalities., https://doi.org/10.1002/9780470996973.ch9.

Del Boca, D., N. Oggero, P. Profeta, M. Ross. 2020. Women's and Men's Work, Housework and Childcare, before and during COVID-19. Review of Economics of the Household 18 (4): 1001-1017, https://doi.org/10.1007/s11150-020-09502-1.

Collins, P. H. 1990. Black Feminist Thought: Knowledge, Consciousness and the Politics of Empowernment. Boston: Unwin Hyman.

Collins, P. H., S. Bilge. 2016. Intersectionality. Cambridge: Polity Press.

Czymara, C. S., A. Langenkamp, T. Cano. 2020. Cause for Concerns: Gender Inequality in Experiencing the COVID-19 Lockdown in Germany. European Societies 23: 1-14, https://doi.org/10.1080/14616696.2020.1808692.

ČSú 2020. Př́ijmy a životní podminky domácností - 2020. Staženo 9. 6. 2021 (https://www. czso.cz/documents/10180/142681148/16002121kc.pdf/ba0430a2-1a85-4e53-968c79cf86b60db4? version=1.1).

Dudová, R. 2020a. Analýza postaveni sólo matek na pracovním trhu podle šetření EU-SILC 2018. Praha: Aperio. Staženo 10. 10. 2021 (https://aperio.cz/wp-content/ uploads/2020/11/Analyza_solo_matky_na_pracovnim_trhu_201124.pdf).

Dudová, R. 2020b. Mechanismy znevýhodněni sólo matek na pracovním trhu. Praha: Aperio. Staženo 10. 10. 2021 (https://aperio.cz/wp-content/uploads/2020/11/Analyza_ mechanismy_znevyhodneni_201124.pdf).

Esping-Andersen, G. 2002. Why We Need a New Welfare State. Oxford: Oxford University Press.

Feng, Z., K. Savani. 2020. Covid-19 Created a Gender Gap in Perceived Work Productivity and Job Satisfaction: Implications for Dual-Career Parents Working from Home. Gender in Management 35 (7-8): 719-736, https://doi.org/10.1108/GM-07-2020-0202.

Fodor, E., A. Gregor, E. Kovats, J. Koltai 2020. Revolution Unstalled ?: The Impact of the COVID-19 Crisis on the Domestic Division of Labor in Hungary. Gender and Society, online first. Staženo 10. 10. 2021 (https://gendersociety.wordpress.com/2020/05/28/ revolution-u...AR3BsC58vLwr4gXzUD0ra7tvwnyTG4zVe4NSL_Dngiz_k5KM0uoaEJilQIc).

Fraser, N. 2016. Contradictions of Capital and Care. New Left Review 100: 99-117.

Fuller, S., Y. Qian 2021. Covid-19 and The Gender Gap in Employment Among Parents of Young Children in Canada. Gender \& Society. Online first, https://doi. org/10.1177/08912432211001287.

Hašková, H., R. Dudová. 2017. Precarious Work and Care Responsibilities in the Economic Crisis. European Journal of Industrial Relations 17 (1): 1-17, https://doi. org/0.1177/0959680116672279. 


\section{NV STATI / ARTICLES}

Hertz, R., J. Mattes, A. Shook. 2020. When Paid Work Invades the Family: Single Mothers in the COVID-19 Pandemic. Journal of Family Issues, online first, https://doi. org/10.1177/0192513X20961420.

Hipp, L., M. Bünning. 2021. Parenthood as a Driver of Increased Gender Inequality During COVID-19? Exploratory Evidence from Germany. European Societies 23 (S1): S658-S673, https://doi.org/10.1080/14616696.2020.1833229.

Choo, H. Y., M. M. Ferree. 2010. Practicing Intersectionality in Sociological Research:

A Critical Analysis of Inclusions, Interactions, and Institutions in the Study of Inequalities. Sociological Theory 28 (2): 129-149, https:doi.org/10.1111/j.1467-9558.2010.01370.x.

Chung, H., H. Birket, S. Forbes, H. Seo. 2021. Covid-19, Flexible Working, and Implications for Gender Equality in the United Kingdom. Gender \& Society 35 (2): 218-232, https:// doi.org/10.1177/08912432211001304.Kolářová, M. 2008. Na křižovatkách nerovností: gender, třída a rasa/etnicita. Gender, rovné príležitosti, výzkum 9 (2): 1-10.

Korbel, V., D. Prokop. 2020. Distanční výuka na jaře a na podzim. Praha: PAQ Research. Staženo 9. 11. 2021 (https://drive.google.com/file/d/1k4QZVuyCyOUWIZvaCE1JsMj7LqxjP6d/view).

Kř́ižková, A., L. Formánková. 2014. Intersekcionální perspektiva zkoumání dopadů krize na životní dráhy v ČR: Gender, třída, věk (a rodičovství). Gender, rovné přiležitosti, výzkum 15 (2): 61-76, https://doi.org/10.13060/12130028.2014.15.2.131.

McCall, L. 2005. The Complexity of Intersectionality. Signs: Journal of Women in Culture and Society 30 (3): 1771-1800, https://doi.org/10.1086/426800.

Mezzadri, A. 2020. A Crisis Like No Other: Social Reproduction and the Regeneration of Capitalist Life during the COVID-19 Pandemic. Developing Economics, April 20. Staženo 9. 11. 2021 (https://developingeconomics.org/2020/04/20/a-crisis-like-noother-social-reproduction-and-the-regeneration-of-capitalist-life-during-the-covid-19pandemic).

Ozkazanc-Pan, B., A. Pullen. 2021. Reimagining Value: A Feminist Commentary in the Midst of the COVID-19 Pandemic. Gender, Work and Organization 28 (1): 1-7, https://doi. org/10.1111/gwao.12591.

Paloncyová, J., J. Barvíková, S. Höhne, V. Kuchařová. 2019. Neúp/né rodiny. Praha: VúPSV. Staženo 10. 11. 2021 (http://praha.vupsv.cz/fulltext/vz_469.pdf).

Shafer, K., C. Scheibling, M.A. Milkie. 2020. The Division of Domestic Labor before and during the COVID-19 Pandemic in Canada: Stagnation versus Shifts in Fathers' Contributions. Canadian Review of Sociology 57 (4): 523-549, https://doi.org/10.1111/ cars. 12315.

Thomason, B., I. Macias-Alonso. 2020. COVID-19 and Raising the Value of Care. Gender, Work and Organization 27 (5): 705-708, https://doi.org/10.1111/gwao.12461.

Vosko, L. F. 2006. Precarious Employment: towards an Improved Understanding of Labour Market Insecurity. Pp. 3-42 in L. F. Vosko (ed.). Precarious Employment: Understanding Labour Market Insecurity in Canada. Montreal, Kingston: McGill-Queen's University Press.

Život během pandemie. 2020. PAQ Research, IDEA Anticovid, NMS. Staženo 10. 11. 2021 (https://zivotbehempandemie.cz). 
(c) BY-NC Radka Dudová, 2021.

(c) BY-NC Sociologický ústav AV ČR, v. v. i., 2021.

Doc. Mgr. Radka Dudová, Ph.D., je expertkou v oblasti analýzy veřejných politik a institucí, se zaměřením na oblast péče o děti a o seniory a na současné proměny pracovního trhu. Pracuje jako vědecká pracovnice v Sociologickém ústavu AV ČR, v.v.i. Je autorkou rady odborných článků a knih: Otcovství po rozchodu rodičovského páru (2008); Interrupce v České republice: zápas o ženská těla (2012), Postarat se ve stář́. Péče o seniory v rodině (2015). Kontaktní e-mail: radka.dudova@soc.cas.cz.

\section{Tabulka komunikačních partnerek}

\begin{tabular}{|c|c|c|c|c|c|}
\hline Pseudonym & Vzdělání & \begin{tabular}{|l} 
Pracovní postavení \\
v únoru 2020
\end{tabular} & Počet a věk dětí & \begin{tabular}{|l|} 
Datum \\
rozhovoru
\end{tabular} & $\begin{array}{l}\text { V domácnosti } \\
\text { (+ děti) }\end{array}$ \\
\hline \multicolumn{6}{|c|}{ Středočeský kraj } \\
\hline Anna & SŠ & $\begin{array}{l}\text { zaměstnaná na dobu } \\
\text { určitou - poštovní } \\
\text { doručovatelka }\end{array}$ & $\begin{array}{l}\text { jedno dítě, čtyřri } \\
\text { roky }\end{array}$ & $\begin{array}{l}\text { únor } 2020, \\
\text { červen } 2020, \\
\text { prosinec } 2020\end{array}$ & $\begin{array}{l}\text { víkendy } \\
\text { s prrítelem, } \\
\text { oddělené } \\
\text { hospodaření }\end{array}$ \\
\hline Hana & VŠ & $\begin{array}{l}\text { zaměstnaná na dobu } \\
\text { určitou - sociální } \\
\text { pracovnice }\end{array}$ & $\begin{array}{l}\text { jedno dítě, sedm } \\
\text { let }\end{array}$ & $\begin{array}{l}\text { únor } 2020, \\
\text { červen } 2020, \\
\text { listopad } 2020\end{array}$ & sama \\
\hline Laura & VOŠ & $\begin{array}{l}\text { zaměstnaná na dobu } \\
\text { neurčitou - kostymérka }\end{array}$ & $\begin{array}{l}\text { jedno dítě, tři } \\
\text { roky }\end{array}$ & $\begin{array}{l}\text { únor } 2020, \\
\text { červen } 2020, \\
\text { prosinec } 2020 \\
\end{array}$ & se svou matkou \\
\hline Nora & VŠ & DPP - recepční & $\begin{array}{l}\text { jedno dítě, tři } \\
\text { roky }\end{array}$ & $\begin{array}{l}\text { únor } 2020, \\
\text { červen } 2020\end{array}$ & sama \\
\hline Pavla & VŠ & $\begin{array}{l}\text { zaměstnaná na dobu } \\
\text { neurčitou - projektová } \\
\text { manažerka v IT }\end{array}$ & $\begin{array}{l}\text { dvě děti, deset } \\
\text { a sedm let }\end{array}$ & $\begin{array}{l}\text { únor } 2020, \\
\text { červen } 2020, \\
\text { listopad } 2020 \\
\end{array}$ & sama \\
\hline Soňa & SŠ & $\begin{array}{l}\text { zaměstnaná na dobu } \\
\text { určitou - asistentka } \\
\text { pedagoga; OSVČ - } \\
\text { fotografka }\end{array}$ & $\begin{array}{l}\text { jedno dítě, osm } \\
\text { let }\end{array}$ & $\begin{array}{l}\text { únor } 2020, \\
\text { červen } 2020, \\
\text { listopad } 2020\end{array}$ & sama \\
\hline Stela & VŠ & DPP - skladnice & $\begin{array}{l}\text { tři děti, dvanáct, } \\
\text { devět a pět let }\end{array}$ & $\begin{array}{l}\text { únor } 2020, \\
\text { červen } 2020, \\
\text { listopad } 2020 \\
\end{array}$ & sama \\
\hline
\end{tabular}

